\title{
Investigation on effect of time of planting in cucumber (Cucumis sativus L.) under polyhouse conditions in Manipur, India
}

\author{
Mrinalini Longjam* and Ak. Bijaya Devi \\ INDIA \\ *Corresponding author. E-mail: mrinalongjam@gmail.com \\ Received: December 2, 1016; Revised received: February 28, 2017; Accepted: August 9, 2017
}

Department of Horticulture, College of Agriculture, Central Agricultural University, Imphal-795004 (Manipur),

\begin{abstract}
An experiment on the standardization of time of planting for growing cucumber(Cucumis sativus L.) inside polyhouse was conducted during 2010-11 at the Horticutural Experimental Field, College of Agriculture, Central Agricultural University, Imphal (Manipur), India. The experiment comprised of four dates of planting (September, October, November and December) and two cucumber varieties viz.Alamgir CT 280 and Alamgir CT 380, in Factorial Randomised Block Design with three replications and eight treatments.Impact of time of planting was established on vegetative characters; flowering and fruiting characters; yield and yielding attributes. Effect of different time of planting and variety on growth of cucumber was found to produce significant effect (at $5 \%$ level of probability) on main vine length, numbers of leaves per plant and leaf area. For both the varieties, September planting gave maximum values of main vine length $(221.93 \mathrm{~cm}$ and $240.51 \mathrm{~cm}$, respectively), number of leaves per plant $(21.21$ and 21.92 , respectively) and leaf area $\left(393.26 \mathrm{~cm}^{2}\right.$ and $413.76 \mathrm{~cm}^{2}$, respectively). The treatment combination of September planting with Alamgir CT 280 gave shorter number of days (12.6) from fruit set to maturity. The different time of planting and varieties and their interactions showed significant effect on number of fruits per plant, fruit length $(\mathrm{cm})$, fruit diameter $(\mathrm{cm})$, single fruit weight $(\mathrm{g})$, fruit yield/plant $(\mathrm{kg})$ and fruit yield/ha $(\mathrm{t})$. The results revealed that the treatment combination of September planting with Alamgir CT 380 gave the highest yield (47.31t/ha), as compared with October, November and December plantings. However, the maximum cost- benefit ratio (1: 2.24) was found in October planting. The present study suggests that cucumber can be grown successfully during winter months under polyhouse in Manipur, India condition.
\end{abstract}

Keywords: Cost-benefit ratio, Cucumber, Time of planting, Polyhouse, Yield

\section{INTRODUCTION}

Cucumber is a major cultivated vegetable crop worldwide and was probably originated in India(Hazra and Som, 2006).It develops rapidly with a shorter time from planting to harvest than most of the crops (Wehner and Guner, 2004). Cucumber is grown extensively as a field crop in most areas of the world under frost free conditions (George, 1990) and also regarded as one of the most preferred vegetable grown under protected conditions in the developed countries, on a commercial basis, which sells at a premium price in off -season. Although a huge number of high yielding hybrids of cucumber varying widely in respect to their yield potential, adaptability and response to inputs have been released for cultivation in open fields (Kaddi et al., 2014), yet the information on the performance of cucumber hybrids under protected cultivation is meagre.

The use of plastic films for covering the greenhouse structures have opened up new avenue for research and commercialization of greenhouse technology where the plants are grown under controlled or partially con- trolled environment resulting in higher yields than that is possible under open conditions (Navale et al., 2003). The interest from protected cucumber cultivation as a means of intensifying crop production is increasing. One of the reasons which help the success of cucumber production under plastic tunnels is that cucumber is a semi-tropical vegetable and grows best under conditions of high light, humidity, moisture, temperature and fertilizer (Wittwer and Honma, 1979). The favourable air temperature, optimum relative humidity and light intensity present in the structure, which had helped in getting good vegetative and reproductive characters ultimately increased yields under polyhouse conditions (Basavaraja et al., 2003). Season, spacing and time of planting has a great effect on the seed yield and quality in cucumber (Kishor et al.,2010). Optimum sowing time brings about proper growth and development of plants resulting in maximum yield of the crop and economic use of land (Islam et al., 2010).

Keeping in view there is urgent need to standardize the time of planting of cucumber under low cost greenhouses so that farmers get remunerative prices from the market. As a step towards it, the present investiga- 
tion was undertaken.

\section{MATERIALS AND METHODS}

Characterization of experimental site: The experiment was conducted at the Horticultural Experimental Farm of the College of Agriculture, Central Agricultural University, Imphal under polyhouse conditions. The farm is situated at an altitude of $790 \mathrm{~m}$ above sea level at $24^{\circ} 45^{\prime} \mathrm{N}$ latitude and $93^{\circ} 56^{\prime} \mathrm{E}$ longitudes, experiencing severe winter and hot summer with mean annual rainfall of $1500 \mathrm{~mm}$, minimum and maximum temperature of $4 \pm 1$ and $34 \pm 2{ }^{\circ} \mathrm{C}$, respectively. The mean data on temperature recoded during the experimental period is presented in Table 1 .

Experimental details: The experiment was laid out in factorial randomized block design with each treatment being replicated three times and with two varieties of cucumber. There were 24 plots (size $1.8 \mathrm{~cm} \mathrm{x} 1.8 \mathrm{~cm}$ ). The experiment consisted of eight treatment combinations comprising of four dates of planting viz. $\mathrm{D}_{1}-$ September sowing, $\mathrm{D}_{2}-$ October sowing, $\mathrm{D}_{3}-$ November sowing and $\mathrm{D}_{4}-$ December sowing and two varieties of cucumber viz. $\mathrm{V}_{1}$ - Alamgir CT 280 and $\mathrm{V}_{2}$ - Alamgir CT 380.The experimental site was prepared manually and the soil was made to a fine tilth after removing the weeds and stubbles. Two seeds were sown per hole at a spacing of $60 \mathrm{~cm} \mathrm{x} 60 \mathrm{~cm}$ which were later thinned down to one plant per stand 2 weeks after planting. Five plants from the net plot were tagged from which the growth and yield parameters were recorded. The recommended dose of FYM@1.5 $\mathrm{kg} / \mathrm{m}^{2}$ and chemical fertilizer@50:50:50 kg/ha of N, P and $\mathrm{K}$ were applied one day before sowing as basal through urea, single super phosphate and muriate of potash respectively (Swarup, 2006). Later $50 \mathrm{~kg} / \mathrm{ha}$ of nitrogen was supplied in two splits, one at 35 days after sowing and the other at 55 days after sowing. Cultural practices, including irrigation and fertilization, were carried out following the standard commercial procedures. Spraying for pests and diseases were applied whenever it appeared necessary throughout the growing season. Vines were vertically trained with bamboo stakes and thread. Harvesting of the cucumber fruits was done by handpicking as and when required. The parameters recorded were main vine length, number of leaves/plant, leaf area, number of days to first female flower after planting, number of days from fruit set to maturity, nodal position of first female flower, yield and yielding parameters. Five random plants from each treatment were used for determining all the vegetative characters at an interval of 10 days starting from 20 days after planting upto 70 days after planting (DAP). The leaf area was calculated by using the formula as given by Robbins and Pharr (1987). Total fruit yield was the accumulated records of fruits over the entire harvesting periods. Economics of cucumber production under polyhouse was worked out by considering the present price of inputs and produce.

Statistical interpretation: The experimental layout was set to be $4 \times 2$ factorial design with three replications. Statistical conclusions were drawn by factorial analysis of the database using OPSTAT. The analysis of variance (ANOVA) was performed to find out the significance of variation among the treatments while the statistical significance of various effects was tested at $5 \%$ probability level.

\section{RESULTS AND DISCUSSION}

Vegetative traits: Effect of different time of planting and variety on growth of cucumber was found to produce significant effect at 5\% level of probability on main vine length, numbers of leaves per plant and leaf area under polyhouse condition. It was observed that the main vine length of cucumber differed significantly due to time of planting, varieties and their interactions at all stages of crop growth viz., 20, 30, 40, 50, 60 and 70 days after planting (DAP) and there was increasing trend at diminishing rate in the main vine length with the advancing of days (Table 2). The growth rate was found to be maximum at 40 DAP. $V_{1}$ and $V_{2}$ when planted in September $\left(D_{1}\right)$ produced maximum vine length $(221.93 \mathrm{~cm}$ and $240.51 \mathrm{~cm}$, respectively) at 70 DAP which were significantly higher at 5\% level of probability than other time of planting i.e. $\mathrm{D}_{2}, \mathrm{D}_{3}$ and $\mathrm{D}_{4}$ whereas minimum main vine length $(88.94 \mathrm{~cm}$ and $98.52 \mathrm{~cm}$, respectively) at the same stage was recorded when planted in the month of December $\left(D_{4}\right)$ in both the varieties.

The interaction effect of the different time of planting and varieties at 40 DAP on main vine length of cucumber is shown in Table 3. At $40 \mathrm{DAP}, \mathrm{V}_{2}$ recorded the mean of $79.57 \mathrm{~cm}$ of main vine length which is signifi-

Table 1. Mean data on temperature recorded during the experimental period.

\begin{tabular}{|c|c|c|c|c|}
\hline \multirow{3}{*}{ Month and year } & \multicolumn{2}{|c|}{ Open field } & \multicolumn{2}{|c|}{ Polyhouse } \\
\hline & \multicolumn{2}{|c|}{ Temperature $\left({ }^{\circ} \mathrm{C}\right)$} & \multicolumn{2}{|c|}{ Temperature $\left({ }^{\circ} \mathrm{C}\right)$} \\
\hline & Maximum & Minimum & Maximum & Minimum \\
\hline Sept. 2010 & 28.6 & 21.6 & 39.3 & 27.7 \\
\hline Oct. 2010 & 27.6 & 18.5 & 37.9 & 23.4 \\
\hline Nov. 2010 & 25.3 & 12.7 & 34.6 & 16.9 \\
\hline Dec. 2010 & 21.6 & 7.3 & 30.8 & 9.0 \\
\hline Jan. 2011 & 20.8 & 5.4 & 29.6 & 10.4 \\
\hline Feb. 2011 & 23.2 & 7.2 & 33.4 & 11.3 \\
\hline
\end{tabular}

Source: ICAR Research Centre, North-eastern Hill Region, Imphal, Manipur, India, 2010-11. 
Table 2. Mean of main vine length $(\mathrm{cm})$, number of leaves per plant and leaf area $\left(\mathrm{cm}^{2}\right)$ of cucumber as influenced by the interaction of time of planting and variety under polyhouse condition.

\begin{tabular}{|c|c|c|c|c|c|c|}
\hline \multicolumn{7}{|c|}{ Main vine length (cm) } \\
\hline Treatments & 20 DAP & 30 DAP & 40 DAP & 50 DAP & 60 DAP & 70 DAP \\
\hline \multicolumn{7}{|l|}{$\mathrm{V}_{1}$} \\
\hline $\mathrm{D}_{1}$ & 2.33 & 5.00 & 11.58 & 17.25 & 20.25 & 21.12 \\
\hline $\mathrm{D}_{2}$ & 1.80 & 4.08 & 8.88 & 13.40 & 16.65 & 17.17 \\
\hline $\mathrm{D}_{3}$ & 1.58 & 2.17 & 7.12 & 10.17 & 13.15 & 14.17 \\
\hline $\mathrm{D}_{4}$ & 1.50 & 2.23 & 6.60 & 9.20 & 11.53 & 13.57 \\
\hline \multicolumn{7}{|l|}{$\mathrm{V}_{2}$} \\
\hline $\mathrm{D}_{1}$ & 2.68 & 6.52 & 12.68 & 18.33 & 20.88 & 21.92 \\
\hline $\mathrm{D}_{2}$ & 1.88 & 4.17 & 9.32 & 15.83 & 17.67 & 18.08 \\
\hline $\mathrm{D}_{3}$ & 1.78 & 3.67 & 9.02 & 13.61 & 15.47 & 15.92 \\
\hline $\mathrm{D}_{4}$ & 1.55 & 1.93 & 6.57 & 10.23 & 12.83 & 13.85 \\
\hline $\operatorname{SE} d( \pm)$ & 0.06 & 0.43 & 0.33 & 0.44 & 0.36 & 0.32 \\
\hline C.D $(5 \%)$ & 0.13 & 0.93 & 0.71 & 0.94 & 0.78 & 0.70 \\
\hline \multicolumn{7}{|c|}{ Number of leaves/plant } \\
\hline \multicolumn{7}{|c|}{$\mathrm{V}_{1}$} \\
\hline $\mathrm{D}_{1}$ & 2.33 & 5.00 & 11.58 & 17.25 & 20.25 & 21.12 \\
\hline $\mathrm{D}_{2}$ & 1.80 & 4.08 & 8.88 & 13.40 & 16.65 & 17.17 \\
\hline $\mathrm{D}_{3}$ & 1.58 & 2.17 & 7.12 & 10.17 & 13.15 & 14.17 \\
\hline $\mathrm{D}_{4}$ & 1.50 & 2.23 & 6.60 & 9.20 & 11.53 & 13.57 \\
\hline \multicolumn{7}{|l|}{$\mathrm{V}_{2}$} \\
\hline $\mathrm{D}_{1}$ & 2.68 & 6.52 & 12.68 & 18.33 & 20.88 & 21.92 \\
\hline $\mathrm{D}_{2}$ & 1.88 & 4.17 & 9.32 & 15.83 & 17.67 & 18.08 \\
\hline $\mathrm{D}_{3}$ & 1.78 & 3.67 & 9.02 & 13.61 & 15.47 & 15.92 \\
\hline $\mathrm{D}_{4}$ & 1.55 & 1.93 & 6.57 & 10.23 & 12.83 & 13.85 \\
\hline $\mathrm{SE} d( \pm)$ & 0.06 & 0.43 & 0.33 & 0.44 & 0.36 & 0.32 \\
\hline C.D $(5 \%)$ & 0.13 & 0.93 & 0.71 & 0.94 & 0.78 & 0.70 \\
\hline \multicolumn{7}{|c|}{ Leaf area $\left(\mathrm{cm}^{2}\right)$} \\
\hline \multicolumn{7}{|l|}{$\mathrm{V}_{1}$} \\
\hline $\mathrm{D}_{1}$ & 158.64 & 232.05 & 370.56 & 390.6 & 393.26 & 389.19 \\
\hline $\mathrm{D}_{2}$ & 117.28 & 207.35 & 327.07 & 347.09 & 349.08 & 345.06 \\
\hline $\mathrm{D}_{3}$ & 107.11 & 179.88 & 311.85 & 332.51 & 335.14 & 331.11 \\
\hline $\mathrm{D}_{4}$ & 98.09 & 170.05 & 300.25 & 320.26 & 323.59 & 319.55 \\
\hline \multicolumn{7}{|l|}{$V_{2}$} \\
\hline $\mathrm{D}_{1}$ & 179.16 & 237.71 & 394.74 & 413.76 & 415.75 & 411.71 \\
\hline $\mathrm{D}_{2}$ & 143.46 & 212.79 & 333.64 & 353.97 & 355.96 & 351.92 \\
\hline $\mathrm{D}_{3}$ & 122.50 & 195.22 & 320.11 & 340.13 & 342.12 & 338.08 \\
\hline $\mathrm{D}_{4}$ & 108.54 & 181.02 & 302.37 & 322.71 & 326.05 & 321.24 \\
\hline $\mathrm{SE} d( \pm)$ & 3.34 & 2.57 & 4.96 & 4.88 & 4.8 & 4.74 \\
\hline C.D $(5 \%)$ & 7.17 & 5.51 & 10.64 & 10.48 & 10.3 & 10.17 \\
\hline
\end{tabular}

$\mathrm{DAP}=$ Days after planting, $\mathrm{V}_{1}=$ Alamgir CT 280, $\mathrm{V}_{2}=$ Alamgir CT 380, $\mathrm{D}_{1}, \mathrm{D}_{2}, \mathrm{D}_{3}$ and $\mathrm{D}_{4}$ represents September, October, November and December planting respectively.

cantly higher than that of $\mathrm{V}_{1}(69.68 \mathrm{~cm})$. Among the different date of planting, $\mathrm{D}_{1}$ recorded maximum main vine length $(125.81 \mathrm{~cm})$ followed by $\mathrm{D}_{2}(65.97 \mathrm{~cm})$ and the minimum $(50.77 \mathrm{~cm})$ in $\mathrm{D}_{4}$ and difference between the means of different treatments of time of planting were significant. Among the interactions, the maximum main vine length $(129.61 \mathrm{~cm})$ was recorded by $\mathrm{V}_{2} \mathrm{D}_{1}$ followed by $\mathrm{V}_{1} \mathrm{D}_{1}(122.01 \mathrm{~cm})$ and the minimum main vine length $(44.44 \mathrm{~cm})$ was observed at $\mathrm{V}_{1} \mathrm{D}_{4}$. Our observations in this regard have been substantiated by findings of several other workers like Karlsen (1981); Klapwijk (1987) and Papadopoulos and Hao (2000) while working on cucumber grown under different greenhouse temperature conditions who found out that a higher temperature of $30^{\circ} \mathrm{C}$ or more produced maximum growth of aerial parts in long English cucumber. Parvej et al. (2010) also stated that the vegetative growth and development of plant becomes restricted during the cold winter months due to decline in temperature.

Similar trend was observed in case of number of leaves per plant (Table 2). It was observed that the two varieties $V_{1}$ and $V_{2}$ when planted in the month of September $\left(D_{1}\right)$ produced maximum number of leaves per plant (21.12 and 21.92, respectively) at 70 DAP which were significantly higher than other time of planting whereas the minimum number of leaves per plant (13.57 and 13.85, respectively) was recorded at the same stage when planting was done in December.

The interaction effect of time of planting and variety of cucumber at 40 DAP on number of leaves per plant is presented in Table 3 . It was observed that $\mathrm{V}_{2}$ recorded 
Mrinalini Longjam and Ak. Bijaya Devi / J. Appl. \& Nat. Sci. 9 (3): 1651 -1657 (2017)
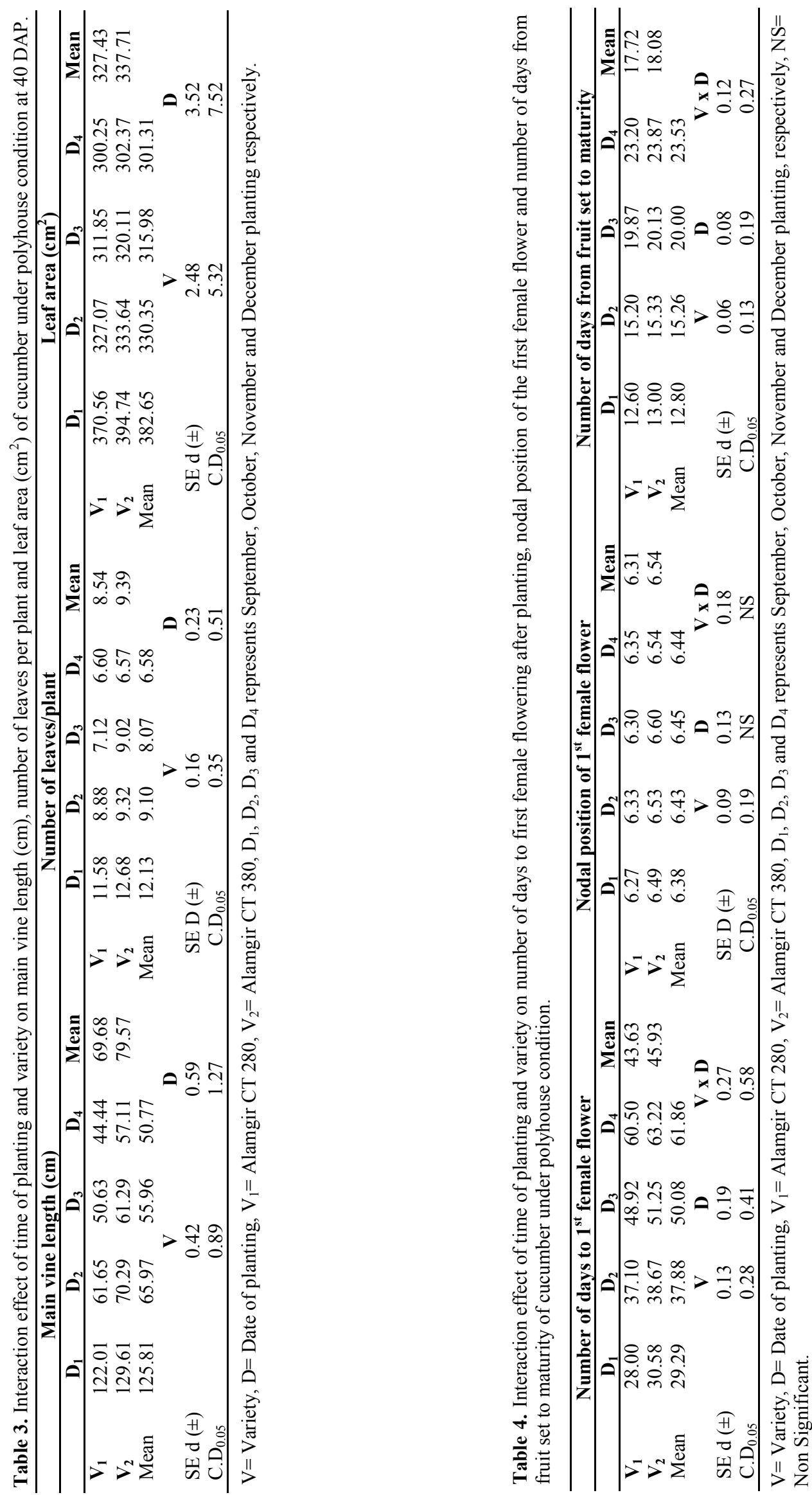
Table 5. Mean of yield and yielding parameters of cucumber as influenced by the interaction of time of planting and variety under polyhouse condition.

\begin{tabular}{lllllll}
\hline Treatments & $\begin{array}{l}\text { No. of fruits/ } \\
\text { plant }\end{array}$ & $\begin{array}{l}\text { Fruit length } \\
\text { (cm) }\end{array}$ & $\begin{array}{l}\text { Fruit diame- } \\
\text { ter (cm) }\end{array}$ & $\begin{array}{l}\text { Fruit weight } \\
(\mathbf{g})\end{array}$ & $\begin{array}{l}\text { Total fruit yield// } \\
\text { plant (kg) }\end{array}$ & $\begin{array}{l}\text { Fruit yield/ha } \\
\text { (t) }\end{array}$ \\
\hline Alamgir CT 280 & & & & & & \\
September & 5.83 & 20.51 & 5.55 & 255.07 & 1.49 & 41.39 \\
October & 5.13 & 18.48 & 5.16 & 227.03 & 1.18 & 32.78 \\
November & 4.77 & 12.30 & 4.64 & 192.84 & 0.92 & 25.46 \\
December & 3.47 & 10.99 & 4.16 & 162.28 & 0.56 & 15.64 \\
Alamgir CT 380 & & & & & & 47.31 \\
September & 6.43 & 20.64 & 5.62 & 264.88 & 1.70 & 37.03 \\
October & 5.55 & 19.80 & 5.44 & 240.14 & 1.33 & 28.70 \\
November & 4.70 & 13.00 & 4.58 & 192.68 & 1.03 & 17.40 \\
December & 3.50 & 12.73 & 4.34 & 177.85 & 0.63 & 0.9 \\
SE d (土) & 0.16 & 0.38 & 0.07 & 2.85 & 0.03 & 1.9 \\
C.D 0.05 & 0.33 & 0.83 & 0.16 & 6.11 & 0.07 & \\
\hline
\end{tabular}

Table 6. Interaction effect of time of planting and variety on yield/hectare $(t)$ of cucumber under polyhouse condition.

\begin{tabular}{|c|c|c|c|c|c|}
\hline & $\mathbf{D}_{1}$ & $\mathbf{D}_{2}$ & $\mathbf{D}_{3}$ & $\mathbf{D}_{4}$ & Mean \\
\hline$V_{1}$ & 41.39 & 32.31 & 25.46 & 15.64 & 28.70 \\
\hline$V_{2}$ & 47.31 & 37.03 & 28.70 & 17.40 & 32.61 \\
\hline Mean & 44.35 & 34.67 & 27.08 & 16.52 & \\
\hline & & V & & D & \\
\hline $\operatorname{SE~d~}( \pm)$ & & 0.4 & & 0.6 & \\
\hline C.D ${ }_{0.05}$ & & 0.9 & & 1.3 & \\
\hline
\end{tabular}

maximum number of leaves per plant (9.39) under September planting $\left(\mathrm{D}_{1}\right)$ which was significantly superior over the other dates of planting. The least number of leaves per plant (8.54) was recorded by $\mathrm{V}_{1}$ under December planting $\left(D_{4}\right) . V_{1}$ and $V_{2}$ were found to be significantly different from each other with respect to number of leaves per plant. With respect to time of planting, $D_{1}$ recorded maximum number of leaves per plant (12.13) and the minimum (6.58) was recorded in $\mathrm{D}_{4}$. Among the interactions, the highest number of leaves per plant (12.68) was recorded by $V_{2} D_{1}$ and the lowest (6.60) by $\mathrm{V}_{1} \mathrm{D}_{4}$. This finding is also supported by Klapwijk (1987) who found out that growth of leaves and fruits in cucumber plant was negligible at lower temperature $\left(15^{\circ} \mathrm{C}\right)$ but was accelerated at temperatures upto and above $30^{\circ} \mathrm{C}$, provided moisture was adequate. Watako (2015) also reported that the number of leaves is maximum (14.5) at week 4 when cucumber is grown under higher optimum temperature $\left(32^{\circ} \mathrm{C}\right)$ under glasshouses.

The different time of planting as well as variety significantly influenced leaf area at all the growth stages (Table 2). The leaf area was found to increase rapidly from 20 to 40 DAP at which the growth rate was maximum at 40 DAP and thereafter it increased at diminishing rate up to 60 DAP and later it declined gradually. The highest leaf area $\left(393.26 \mathrm{~cm}^{2}\right.$ and $415.75 \mathrm{~cm}^{2}$, respectively) was observed at 60 DAP when $V_{1}$ and $V_{2}$ were planted in $D_{1}$ and the lowest $\left(319.55 \mathrm{~cm}^{2}\right.$ and $321.24 \mathrm{~cm}^{2}$, respectively) at the same stage was observed in $\mathrm{D}_{4}$.

The interaction effect of time of planting and variety on leaf area of cucumber at 40 DAP is shown in Table
3 and it revealed that $V_{1}$ and $V_{2}$ were found to differ significantly in leaf area at 40 DAP. The maximum leaf area $\left(337.71 \mathrm{~cm}^{2}\right)$ was recorded by $V_{2}$ and the minimum by $\mathrm{V}_{1}\left(327.43 \mathrm{~cm}^{2}\right)$. Among the different time of planting, the maximum $\left(382.65 \mathrm{~cm}^{2}\right)$ and minimum $\left(301.31 \mathrm{~cm}^{2}\right)$ leaf area was observed in $\mathrm{D}_{1}$ and $\mathrm{D}_{4}$, respectively. At $40 \mathrm{DAP}$, the interaction of different time of planting and variety was found to produce significant influence on leaf area of the crop. Among the interactions, the maximum leaf area $\left(394.74 \mathrm{~cm}^{2}\right)$ was recorded by $\mathrm{V}_{2} \mathrm{D}_{1}$ and the minimum $\left(300.25 \mathrm{~cm}^{2}\right)$ by $\mathrm{V}_{1} \mathrm{D}_{4}$. The increase in leaf area in $\mathrm{D}_{1}$ may be due to availability of higher light intensity and temperature resulting in production of more active leaves and also affecting leaf physiology which finally increased leaf photosynthesis (Watako, 2015). This finding is also in agreement with the findings of Marcelis (1993) and Slack and Hand (1983) which reported that leaf expansion, total leaf area $\left(3.45 \mathrm{~m}^{2} /\right.$ plant $)$ and leaf weight $(1.36 \mathrm{~g} / \mathrm{leaf})$ in Fabrio and Sandra cucumber variety were greater at higher temperature $\left(25^{\circ} \mathrm{C}\right)$ than at $18^{\circ} \mathrm{C}$ in the early stage of growth.

Flowering and maturity characters: From Table 4, it was observed that the shortest number of days for appearance of first female flower was recorded by $D_{1}$ (29.29) which were significantly shorter than the longest number of days at $\mathrm{D}_{4}(61.86)$. Moreover, the difference between the two varieties i.e. $V_{1}$ and $V_{2}$ was also significant. $\mathrm{V}_{1}$ recorded shorter number of days (43.63) to anthesis of first female flower than $V_{2}$ (45.93). The interactions of different time of planting and different varieties significantly $(5 \%$ level of probability) affected the number of days taken to produce 
the first female flower. In this case, the shortest number of days to appearance of first female flower was recorded at treatment combination $\mathrm{V}_{1} \mathrm{D}_{1}(28.00)$ which were significantly shorter than that of the longest at $\mathrm{V}_{2}$ $\mathrm{D}_{4}(63.22)$.

The effect of time of planting and variety on nodal position of first female flower of cucumber is presented in Table 4 and it was observed that there was no significant difference in the means. It was also observed that the interaction between the different time of planting and the varieties did not exhibit any significant difference on the node number of the first female flower appearance. However, only the different varieties $V_{1}$ and $V_{2}$ had a significant effect on this character. $V_{1}$ recorded minimum (6.31) node number of first female flower than $V_{2}$ (6.54). Our observation is in agreement with the findings of several other workers like Wehner and Guner (2004) who found out that growth stages like days to flowering and fruit harvest were reached in fewer days (40 days to $100 \%$ fruit harvest) when the temperature was higher in cucumber cultigens Calypso.Kishor et al. (2010) also observed that cucumber grown during seasons with higher temperature and humidity were shorter by 10 days as compared to others.

The two varieties $V_{1}$ and $V_{2}$ were found to be significantly different for number of days from fruit set to maturity where $V_{1}$ recorded shorter number of days (17.72) for fruit set to maturity than $V_{2}$ (18.08), presented in Table 4. Regarding the different time of planting, the minimum (12.8) and maximum (23.53) number of days from fruit set to maturity was observed in $\mathrm{D}_{1}$ and $\mathrm{D}_{4}$, respectively which were significantly different. In case of the interactions (Table 4), significant influence was observed in the days taken from fruit set to maturity where the shortest days from fruit set to maturity was recorded at $V_{1} D_{1}(12.6)$ followed by $V_{2} D_{1}(13.00)$ and the longest at $V_{2} D_{4}(23.87)$. It has been earlier noted by other workers like Slack and Hand (1983) that higher temperature in the early stage of growth promotes flowering, fruit development and early yield in cucumber cvs Fabrio. Such results are also in agreement with Islam et al. (2010) who revealed that the favourable environment received by the greenhouse crop like sweet pepper in the early stage of growth enhances early flowering and fruiting which led to higher yield production.

Yield and yield components: Data on yield and yielding parameters (Table 5) revealed that there were significant differences among the different treatments. The maximum number of fruits per plant, fruit length, fruit diameter, single fruit weight, fruit yield per plant and fruit yield per hectare were recorded from $D_{1} V_{2}$ i.e. Alamgir CT $380\left(\mathrm{~V}_{2}\right)$ under September planting $\left(\mathrm{D}_{1}\right)$, shown in Table 5 .

The highest number of fruits per plant (5.83 and 6.43 for $V_{1}$ and $V_{2}$, respectively) was observed when plant- ed in September and the lowest (3.47 and 3.50 for $\mathrm{V}_{1}$ and $V_{2}$, respectively) in December planting $\left(D_{4}\right)$.

Similar trends were observed in case of fruit length, fruit diameter and single fruit weight as that of number of fruits per plant (Table 5). The highest mean fruit length, fruit diameter as well as single fruit weight was recorded in September $\left(D_{1}\right)$ for both $V_{1}$ and $V_{2}$ and the lowest of the same in December $\left(D_{4}\right)$. For total fruit yield per plant, the highest mean was recorded when planting was done in September $\left(\mathrm{D}_{1}\right)$ followed by October $\left(D_{2}\right)$ and the lowest at December $\left(D_{4}\right)$. The highest mean yield per hectare was recorded at September planting, $D_{1}(44.35 \mathrm{t})$ followed by October, $\mathrm{D}_{2}$ (34.67 t) and the lowest at December, $D_{4}(16.52 \mathrm{t})$. The interaction of September planting with Alamgir CT 380 $\left(\mathrm{D}_{1} \mathrm{~V}_{2}\right)$ and December planting with Alamgir CT 280 $\left(\mathrm{D}_{4} \mathrm{~V}_{1}\right)$ recorded maximum $(47.31 \mathrm{t})$ and minimum $(15.64 \mathrm{t})$ fruit yield per hectare respectively (Table 6). This finding is in agreement with the findings of Papadopoulos and Hao (2000) which stated that fruit size ( $457 \mathrm{~g} /$ fruit) and overall yield increased with increasing daily air temperature under polyhouse in Corona variety of cucumber. Nangare et al. (2015) also reported that the better growth, development and yield $(3.49 \mathrm{~kg} /$ plant) of tomato variety Naveen were achieved under shade net due to optimum temperature $\left(22^{\circ} \mathrm{C}\right)$ and humidity (78\%).

The results obtained with $\mathrm{V}_{2}$ i.e. Alamgir CT 380 in September planting showed high yield in the polyhouse conditions. However, the cost: benefit ratio was highest in October planting $(1: 2.24)$ which is due to the fact that the price of cucumber was high in NovemberDecember than October-November. Singh et al. (2007) stated that low cost naturally ventilated greenhouses are more suitable and economical for year round cultivation of cucumber giving a cost benefit ratio of 1:2.29. Mishra et al. (2007) also found that the cost benefit ratio for greenhouse and greenhouse with shade net was 2.56 and 2.75 respectively and 1.26 for open field cultivation of cucumber.

\section{Conclusion}

Planting of cucumber under well ventilated polyhouse condition for off-season production during the month of September resulted in the highest fruit yield (47.31t/ ha). However, from economic point of view, production was found to be beneficial when sowing was done in October with the variety Alamgir CT 380 which gave profitable net return as well as the highest costbenefit ratio (1:2.24).Ultimately, this study revealed that cucumber cultivation under polyhouse conditions during winter months in Manipur, India is promising.

\section{REFERENCES}

Basavaraja, N., Nandi, V. R. and Praveen, J. (2003). Protected cultivation of capsicum and bhindi. Proc. All India Sem. Potential Prospects for Protective Cultivation, 
Institute of Engineers, Ahmednagar, India, December 12-13, 2003, pp. 197-199.

George, W. L. (1990). Genetic and environmental modification of determinate plant habit in cucumbers. J. Amer. Soc. Hort. Sci. 95: 583-586.

Hazra, P. and Som, M.G. (2006). Vegetable Science, Kalyani Publishers, New Delhi, India.

Islam, M., Saha, S., Akand, H. and Rahim, A. (2010). Effect of sowing date on the growth and yield of sweet pepper (Capsicum annuum L.). Agronomski Glasnik1/2010.

Kaddi, G., Tomar, B.S., Singh, B. and Kumar, S. (2014). Effect of growing conditions on seed yield and quality of cucumber (Cucumis sativus) hybrid. Indian J. Agr. Sci.84: 624-627.

Karlsen, P. (1981). The influence of root and air temperature on young cucumber plants. Acta Hortic. 118: $95-103$

Kishor, S., Tomar, B. S., Singh, B. and Munshi, A. D. (2010). Effect of season, spacing and planting time on seed yield and quality in cucumber. Indian J. Hort.67 (1): 66-69.

Klapwijk, D. (1987). Cucumbers and temperature. Groenten en Fruit42(31): 32-33.

Marcelis, L. F. M. (1993). Leaf formation in cucumber (Cucumis sativus L.) as influenced by fruit load, light and temperature. Gartenbauwissenschaft, 58: 124-129.

Mishra J.N., Paul J.C. and Swain S. (2007). Technoeconomic evaluation of greenhouse and greenhouse with shadenet for off-season cucumber cultivation in coastal climate of Orissa. Agri. Eng. Today, $31(3 \& 4): 21-25$.

Nangare, D.D., Singh, J., Meena, V.S., Bhushan, B. and Bhatnagar, P.R. (2015). Effect of green shade nets on yield and quality of tomato (Lycopersicon esculentum Mill) in semi-arid region of Punjab. Asian J. Adv. Basic Appl. Sci. 1(1): 1-8.
Navale, A. V., Nandagude, S. B., Pawar, A. G., Ghodke, H. M. and Bhosale, A. D. (2003). Comparative study of skirting and top covering effect in low cost greenhouse. In: Proc. All India Sem. Potential Prospects for Protective Cultivation, Institute of Engineers, Ahmednagar, India, December 12-13, 2003,pp. 97.

Papadopoulos, A. P. and Hao, X. (2000). Effects of day and night air temperature on growth productivity and energy use of long English cucumber. Canad. J. Plant Sci. 80: $143-150$

Parvej, M.R., Khan, M.A.H. and Awal, M.A. (2010). Phenological development and production potentials of tomato under polyhouse climate. J. Agric. Sci. 5(1).

Robbins, N.S. and Pharr, D.M. (1987). Leaf area prediction models for cucumber from linear measurements. Hort Sci. 22: 1264-1266.

Slack, G and Hand, D. W. (1983). The effect of day and night temperature on the growth, development and yield of glasshouse cucumbers. J. Hort. Sci. 58: 567-573.

Singh, B.; Kumar, M. and Sirohi, N.P.S. (2007). Technoeconomic feasibility of year-round parthenocarpic cucumber cultivation under naturally ventilated greenhouse in Northern India. Acta Hort.(ISHS) 731:277280.

Swarup, V. (2006). Vegetable Science and Technology in India, Kalyani Publishers, New Delhi, India.

Watako, A.O. (2015). Effect of three covering materials on vegetative growth of cucurbits in Kenya. GARJAS 4(2): 89-94.

Wehner T. C. and Guner N. (2004). Growth stage, flowering pattern, yield and harvest date prediction of four types of cucumber tested at 10 planting dates. Acta Hortic. (ISHS) 637

Wittwer, S.H. and Honma, S. (1979). Greenhouse tomatoes, lettuce and cucumbers. Michigan State University Press, pp. 203-204. 